\title{
NAD(P)H regeneration is the key for heterolactic fermentation of hexoses in Oenococcus oeni
}

\author{
Sergi Maicas, $\uparrow$ Sergi Ferrer and Isabel Pardo
}

Departament de

Microbiologia i Ecologia,

Facultat de Biologia,

Universitat de València, C/Dr

Moliner, 50, Burjassot,

València, Spain 46100-E
Author for correspondence: Isabel Pardo. Tel: +34 6 3864390. Fax: +34 63864372.

e-mail: Isabel.Pardo@uv.es

Oenococcus oeni (formerly Leuconostoc oenos) can perform malolactic fermentation, converting L-malate to L-lactate and carbon dioxide, in wines. The energy and redox potential required to support the growth of the microorganism are supplied mainly by the consumption of carbohydrates via the heterolactic pathway. In the first steps of hexose metabolism two molecules of $N A D(P)^{+}$are consumed, which must be regenerated in later reactions. The aim of this work was to test if aerobic growth of 0 . oeni promotes higher cell yields than anaerobic conditions, as has been shown for other lactic acid bacteria. 0 . oeni M42 was found to grow poorly under aerobic conditions with glucose as the only carbohydrate in the medium. It was demonstrated that $\mathrm{O}_{2}$ inactivates the enzymes of the ethanol-forming pathway, one of the two pathways which reoxidizes $N A D(P)^{+}$cofactors in the heterolactic catabolism of glucose. These results suggest that the regeneration of cofactors is the limiting factor for the aerobic consumption of glucose. When external electron acceptors, such as fructose or pyruvate, were added to glucose-containing culture medium the growth of $O$. oeni was stimulated slightly; fructose was converted to mannitol, oxidizing two molecules of NAD(P)H, and pyruvate was transformed to lactate, enabling the regeneration of $\mathrm{NAD}^{+}$. The addition of cysteine seemed to suppress the inactivation of the ethanol-forming pathway enzymes by $\mathrm{O}_{2}$, enabling glucose consumption in aerobic conditions to reach similar rates to those found in anaerobic conditions.

Keywords: aerobic glucose catabolism, NADH, ethanol-forming pathway, Leuconostoc oenos

\section{INTRODUCTION}

Oenococcus oeni is a lactic acid bacterium able to carry out malolactic fermentation (MLF), which is the bioconversion of malic acid, present in wine, to lactic acid and $\mathrm{CO}_{2}$. The general biochemistry of aerobic carbohydrate metabolism in O. oeni has been successfully elucidated (Salou et al., 1994). O. oeni obtains energy to grow from the catabolism of sugar via heterolactic fermentation. The metabolic end-products of this catabolic pathway are lactic acid, acetic acid, ethanol and

\footnotetext{
†Present address: Facultad de Ciencias Experimentales y de la Salud, Universidad Cardenal Herrera-CEU, Edifici Seminari S/U, 46113, Montcada, Spain.

Abbreviations: ADH, alcohol dehydrogenase; EFP, ethanol-forming pathway; LAB, lactic acid bacteria; MBB, MLO basal broth; MBBG, MLO basal broth plus glucose $(55 \mathrm{mM}) ; X_{\max }$ maximum biomass.
}

$\mathrm{CO}_{2}$ (Fig. 1) (Wibowo et al., 1985; Cogan \& Jordan, 1994). The relative yields of acetic acid and ethanol are related to the availability of $\operatorname{NAD}(\mathrm{P})^{+}$in the cell. $\mathrm{NAD}(\mathrm{P}) \mathrm{H}$ produced during the first steps of the heterolactic catabolism of sugars is reoxidized by the conversion of pyruvic acid to lactic acid, as well as by the conversion of acetyl phosphate to ethanol. Although lactic acid bacteria (LAB) have a fermentative metabolism, some Leuconostoc strains exhibit higher biomass production when cultured in the presence of $\mathrm{O}_{2}$ (Plihon et al., 1995). Under aerobic conditions, $\mathrm{O}_{2}$ acts as an electron acceptor oxidizing $\mathrm{NADP}(\mathrm{H})$ by $\mathrm{NAD}(\mathrm{P}) \mathrm{H}$ oxidases. Other compounds can also be used as electron acceptors, e.g. pyruvic acid or fructose (Ito et al., 1983). Fructose is catabolized by the heterolactic pathway but can also be transformed into mannitol by mannitol dehydrogenase, a collateral reaction where $\mathrm{NAD}(\mathrm{P}) \mathrm{H}$ is regenerated (Veiga-da-Cunha et al., 1993). The channel- 


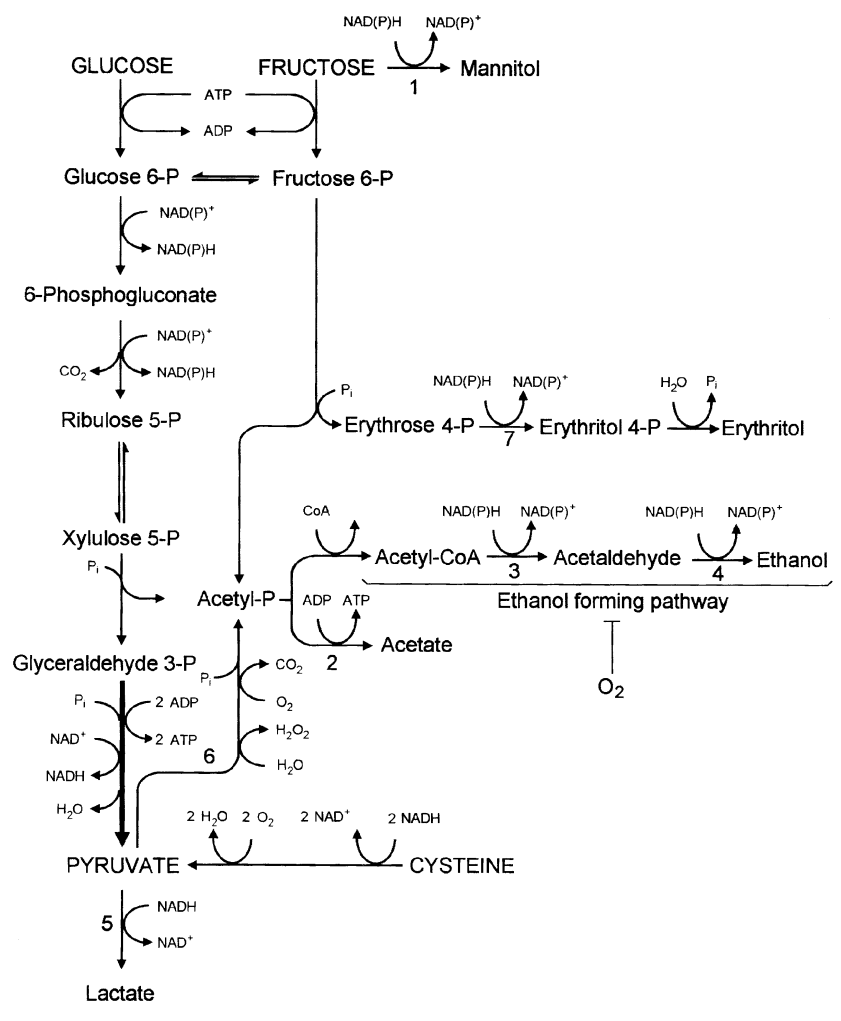

Fig. 1. Schematic representation of carbon and energy flows through the central metabolic pathways of $O$. oeni M42. Numbers represent: 1, mannitol dehydrogenase; 2, phosphate acetyltransferase; 3, acetaldehyde dehydrogenase; 4, ADH; 5, lactate dehydrogenase; 6 , pyruvate oxidase; 7, erythritol-4phosphate dehydrogenase.

ling of sugar through these two alternative pathways depends on the $\mathrm{NAD}(\mathrm{P}) \mathrm{H} / \mathrm{NAD}(\mathrm{P})^{+}$balance within the cell.

The aim of this work was to test whether $\mathrm{O}_{2}$ or other electron acceptors could be used to improve the sugar consumption and growth of O. oeni. Moreover, $\mathrm{NAD}(\mathrm{P}) \mathrm{H}$ oxidases and the ethanol-forming-pathway activities of $O$. oeni have been studied under aerobic and anaerobic conditions. Elucidating such physiological aspects should allow problems associated with the production of malolactic starter cultures to be solved.

\section{METHODS}

Strain cultivation and maintenance. O. oeni CECT M42 was isolated from a Macabeo white wine by Pardo \& Zúñiga (1992) and maintained in $20 \%$ (v/v) glycerol frozen at $-20^{\circ} \mathrm{C}$, or freeze-dried. The strain was grown routinely on medium for Leuconostoc oenos (MLO; Caspritz \& Radler, 1983) and maintained on MLO plates at $4{ }^{\circ} \mathrm{C}$ until needed.

\section{Media and cultivation conditions}

Effect of anaerobic and aerobic conditions on catabolism of sugar and growth. O. oeni M42 was grown in $200 \mathrm{ml} \mathrm{MLO} \mathrm{basal}$ broth (MBB), i.e. MLO without sugars, citrate, tomato juice or cysteine, in a $350 \mathrm{ml}$ Biostat-Q multiple bioreactor (B. Braun). Sugars (glucose or fructose) were supplied to the medium before sterilization at a final concentration of $55 \mathrm{mM}$.
MBB plus $55 \mathrm{mM}$ glucose (MBBG) was used to test the effect of adding external electron acceptors. The compounds added were pyruvate $(20 \mathrm{mM})$, fructose $(20 \mathrm{mM})$, or L-cysteine. $\mathrm{HCl}$ $\left(1 \cdot 5,7 \cdot 5,15\right.$ or $30 \mathrm{mmol} \mathrm{l}^{-1}$; Sigma). In each case the $\mathrm{pH}$ was adjusted to 4.8 with $1 \mathrm{M} \mathrm{KOH}$. After autoclaving, media were supplemented with $0.01 \mathrm{~g} \mathrm{l}^{-1}$ filter-sterilized D-pantothenic acid. The bioreactors were inoculated with an initial biomass concentration of $2 \mathrm{mg} \mathrm{l}^{-1}$ from a pre-culture grown in flasks at $28{ }^{\circ} \mathrm{C}$ for $48 \mathrm{~h}$, without stirring. The cultures in the bioreactors were grown at $28{ }^{\circ} \mathrm{C}$ with constant stirring (200 r.p.m.). The aerobic or anaerobic conditions were obtained by a continuous flush $\left(0.50 \mathrm{l} \mathrm{min}^{-1}\right)$ of sterile air or $\mathrm{N}_{2}$, respectively. $\mathrm{O}_{2}$ partial pressure was continuously controlled and registered in bioreactors to ensure aeration conditions (anaerobic, $\mathrm{pO}_{2}<5 \%$, or aerobic, $\mathrm{pO}_{2}>95 \%$, as required). Microbial growth was recorded by periodic sampling of the culture broth. Optical densities of samples were measured at $600 \mathrm{~nm}$. A calibration curve was constructed to correlate $\mathrm{OD}_{600}$ and dry weight $\left(\mathrm{g}^{-1}\right)$. Specific growth rates were calculated from the cell mass profiles as described by Salou et al. (1994). The changes in $\mathrm{pH}$ of the media were recorded. The concentrations of residual sugars and the final products of fermentation were quantified in the broth at the end of the experiments, by HPLC (see 'Analysis of chemical compounds').

Effect of anaerobic and aerobic conditions on the internal pools of $\mathrm{NADH}$ and NADPH. A separate experiment was designed to determine the effect of aeration conditions on the pool concentrations of the cofactors and on the activity of cell enzymes related to their reoxidation. Cells were grown in 11 MBBG under $\mathrm{N}_{2}$ flushing, in a 21 Biostat-B bioreactor (B. Braun). When the culture reached a level of $0.08 \mathrm{~g}$ cell dry matter per litre, $200 \mathrm{ml}$ was aseptically transferred to another bioreactor and then continuously aerated, whereas the rest of the culture continued growing anaerobically. The experiments lasted $5 \mathrm{~d}$ in both reactors, sparged with either $\mathrm{N}_{2}$ or air. Samples were collected at the end of this period to measure the ethanol forming pathway (EFP) enzyme activities. Duplicate experiments were performed for each culture condition.

Analysis of chemical compounds. Samples were withdrawn directly from the bioreactors through the sampling ports and subsequently stored at $-20^{\circ} \mathrm{C}$. For chemical analysis, supernatants from centrifuged samples (16000 r.p.m., $30 \mathrm{~min}$ ) were filtered through a C-18 cartridge (Sep-Pak, Waters) and then through a $0.22 \mu \mathrm{m}$ membrane filter. The concentrations of sugars, organic acids and ethanol in the fermentation broth were quantified by HPLC using an HPX-87H Aminex ionexclusion column as previously described (Maicas et al., 1999). ATP yields were determined from experimental lactate and acetate concentrations as described by Firme et al. (1994).

Preparation of cell-free extracts. Culture broth was withdrawn from the bioreactor into an ice-cooled bottle, centrifuged and washed twice with $10 \mathrm{mM}$ potassium phosphate buffer ( $\mathrm{pH} 7 \cdot 0,4{ }^{\circ} \mathrm{C}$ ) and once with $3 \mathrm{mM}$ Tris $/ \mathrm{HCl}(\mathrm{pH} 7 \cdot 0$, $4{ }^{\circ} \mathrm{C}$ ). Cells were then resuspended in $2 \mathrm{ml} 6.4 \mathrm{mM}$ Tris $/ \mathrm{HCl}$ $\left(\mathrm{pH} 8.4,4{ }^{\circ} \mathrm{C}\right)$ and disrupted by breaking them in a vortex with 1 vol. of $0.1 \mathrm{~mm}$ glass beads for $10 \mathrm{~min}$. Cells and cell extracts from the anaerobic cultures were maintained under $\mathrm{N}_{2}$ flushing to prevent exogenous oxidation. The suspension was centrifuged (16000 r.p.m., $30 \mathrm{~min}, 2^{\circ} \mathrm{C}$ ) and the cell-free supernatant was pooled in a pre-cooled Eppendorf tube and stored at $-20{ }^{\circ} \mathrm{C}$ for further analyses.

Protein quantification in the cell-free extracts. The Micro BCA Protein Assay Reagent (Pierce) was used to measure the protein concentration in the cell-free extracts, according to the manufacturer's instructions, using BSA as a standard. 
Analysis of in vitro enzyme activities. Enzyme assays were performed at $30^{\circ} \mathrm{C}$ in quartz cuvettes with a $1 \mathrm{~cm}$ light path using a Beckman model DU-7 spectrophotometer. The activity of alcohol dehydrogenase (ADH; EC 1.1.1.1) was measured in $3 \mathrm{ml}$ of a reaction mixture containing $0 \cdot 2 \mathrm{M}$ glycine $/ \mathrm{NaOH}$ buffer ( $\mathrm{pH} 9.0$ ), $3.3 \%$ (v/v) ethanol, $7.5 \mathrm{mM} \beta$-NAD ${ }^{+}$and $150 \mu \mathrm{g}$ protein extract (Klingenberg, 1985). Enzyme activity was calculated using the increase in $A_{340}$ resulting from the coenzyme reduction. The reaction for $\mathrm{ADH}\left(\mathrm{NADP}^{+}\right)(\mathrm{EC}$ 1.1.1.2) activity determination was identical to that described above, except that $\beta-\mathrm{NAD}^{+}$was replaced by $\beta$-NADP ${ }^{+}$. For acetaldehyde dehydrogenase (acetylating) (EC 1.2.1.10) determination, the coenzyme reduction was measured in a final volume of $3 \mathrm{ml}$ containing: $0 \cdot 2 \mathrm{M} \mathrm{K}_{2} \mathrm{HPO}_{4} / \mathrm{KH}_{2} \mathrm{PO}_{4}$ buffer $\mathrm{pH} 7 \cdot 4 ; 10 \mathrm{mM}$ 2-mercaptoethanol; $5 \mathrm{mM}$ acetaldehyde; $50 \mathrm{mM} \beta$-NAD ${ }^{+}$(or $\beta$-NADP ${ }^{+}$); and, $150 \mu \mathrm{g}$ protein extract. Phosphate acetyltransferase (EC 2.3.1.8) activity was determined by measuring acetyl phosphate decomposition in the presence of coenzyme $\mathrm{A}$ and arsenate according to the method of Kelly \& Patchett (1996). NAD(P)H oxidase activities were assayed in $50 \mathrm{mM}$ potassium phosphate buffer $(\mathrm{pH} 7 \cdot 0$ ) containing $1 \mathrm{mM}$ EDTA and $25 \mu \mathrm{m} \beta$-NADH (or $\beta$ NADPH) (Anders et al., 1970). The reactions were started by adding the extract; the decreases in $A_{340}$ were monitored. One unit of enzyme activity was defined as the amount of enzyme reducing $1 \mu \mathrm{mol}$ coenzyme $\min ^{-1}$; the specific activity was expressed as mmol (g protein $)^{-1} \mathrm{~min}^{-1}$. The functionality of the assays was verified with enzymes purchased from Sigma.

Enzyme inactivation in vitro. Protein extracts were obtained from cells grown on MBBG under anaerobic conditions. Cells were recovered from culture medium at late-exponential phase and extracts were made as described above. Extracts were airflushed in $0 \cdot 2 \mathrm{M}$ glycine/ $\mathrm{NaOH}$ buffer for $6 \mathrm{~h}$ (with or without $3 \mathrm{mM}$ cysteine). Samples were periodically withdrawn and ADH activity was measured as described. The enzyme activity of unflushed extracts was recorded and used as a control.

Quantification of cofactors. Assays were performed in cuvettes equilibrated at $30{ }^{\circ} \mathrm{C}$ using a Perkin-Elmer model LS-50 Luminescence spectrometer with excitation at $340 \mathrm{~nm}$ and emission peak at $460 \mathrm{~nm}$. Buffers and stock solutions were prepared with ultrapure water and were filtered through $0 \cdot 1 \mu \mathrm{m}$ filters. Each enzyme was prepared at the highest possible concentration, and fresh dilutions were made each day. Standard solutions of pyrimidine nucleotides were prepared each day and stored on ice. Standard substrate solutions were prepared daily and were assayed spectrophotometrically on the day of use.

$\beta$-NAD ${ }^{+}$quantification was performed in $1.5 \mathrm{ml} 0 \cdot 1 \mathrm{M}$ Tris/ $\mathrm{HCl}$ containing $0.4 \mathrm{M}$ hydrazine hydrate $(\mathrm{pH} 8.5)$. The reaction was started by adding $0.5 \%(\mathrm{v} / \mathrm{v})$ ethanol. When temperature equilibration was completed (1-2 min), $7 \cdot 5 \mu \mathrm{l}$ ADH (EC 1.1.1.1) (566 $\mathrm{U} \mathrm{ml}^{-1}$ ) was added. After $2-3 \mathrm{~min}$, $7 \cdot 5 \mu \mathrm{l}$ standard solution $\left(0 \cdot 1 \mathrm{mM} \beta\right.$-NAD $\left.{ }^{+}\right)$or cell-free extracts were added to the reaction solution. $\beta$-NADH production was measured by reading the increase of fluorescence. $\beta$-NADP ${ }^{+}$ quantification was performed in $1.5 \mathrm{ml} 0.05 \mathrm{M}$ triethanolamine/ $\mathrm{HCl}, 10 \mathrm{mM} \mathrm{MgCl}$, $5 \mathrm{mM}$ EDTA ( $\mathrm{pH} 7 \cdot 4$ ) as described for $\beta$-NAD ${ }^{+}$quantification, but using $0 \cdot 1 \mathrm{M}$ glucose $6-$ phosphate as substrate and $50 \mu \mathrm{M} \beta$-NADP ${ }^{+}$as cofactor. The reaction was catalysed by glucose-6-phosphate dehydrogenase: $\mathrm{NADP}^{+}$oxidoreductase (EC 1.1.1.49) $\left(27 \cdot 8 \mathrm{U} \mathrm{ml}^{-1}\right)$. $\mathrm{NAD}(\mathrm{P}) \mathrm{H}$ quantification was carried out by luminescence as described by Klingenberg (1985). Anaerobic conditions were maintained by $\mathrm{N}_{2}$-flushing to prevent indirect effects, when required.

\section{RESULTS AND DISCUSSION}

\section{Effect of anaerobic or aerobic conditions on growth and metabolic end-products during heterolactic catabolism of sugars}

Glucose was completely metabolized by O. oeni M42 through the heterolactic pathway (Fig. 1) under anaerobic conditions, allowing a high biomass-to-glucose conversion yield, $Y=5.23 \mathrm{~g}$ (mol sugar) ${ }^{-1}$ (Fig. 2). The maximum specific growth rate, $0.08 \mathrm{~h}^{-1}$, corresponded to the first $24 \mathrm{~h}$ of growth. The maximum biomass $\left(X_{\max }\right)$ was $0.30 \mathrm{~g} \mathrm{l}^{-1}$. The analysis of metabolic endproducts showed equimolar amounts of lactate and ethanol in addition to significant levels of acetate (Table $1)$.

The $X_{\max }$ reached by O. oeni grown aerobically on glucose was very poor, $X_{\max }=0.05 \mathrm{~g} \mathrm{l}^{-1}$ (Fig. 2). Less than $5 \%(\mathrm{w} / \mathrm{w})$ of the available glucose was metabolized, and the relative proportions of metabolic endproducts were different to those found under anaerobic conditions (Table 1). These results contrast with those reported by Lucey \& Condon (1986) and Sakamoto \& Komagata (1996), in which Leuconostoc mesenteroides cells cultured aerobically grew better than those cultured anaerobically. LAB do not usually grow well under vigorous aeration and it could be said that the metabolism of LAB in the presence of $\mathrm{O}_{2}$ is unusual. However, Lucey \& Condon (1986) and Sakamoto \& Komagata (1996) found that Leuconostoc mesenteroides cultured aerobically grew better than when cultured anaerobically because of the presence of inducible $\mathrm{NAD}(\mathrm{P}) \mathrm{H}$ oxidases, leading the cells to gain an ATP molecule from the transformation of acetyl phosphate to acetate. Plihon et al. (1995) also reported an improvement in Leuconostoc mesenteroides growth under aerobic conditions when the culture was supplied with sparged air or pure $\mathrm{O}_{2}$. In some cases, LAB do not benefit from $\mathrm{O}_{2}$, but they are not inhibited by its presence, e.g. Lactobacillus plantarum (Murphy \& Condon, 1984) and Lactococcus lactis (Cogan et al., 1989). However, O. oeni M42

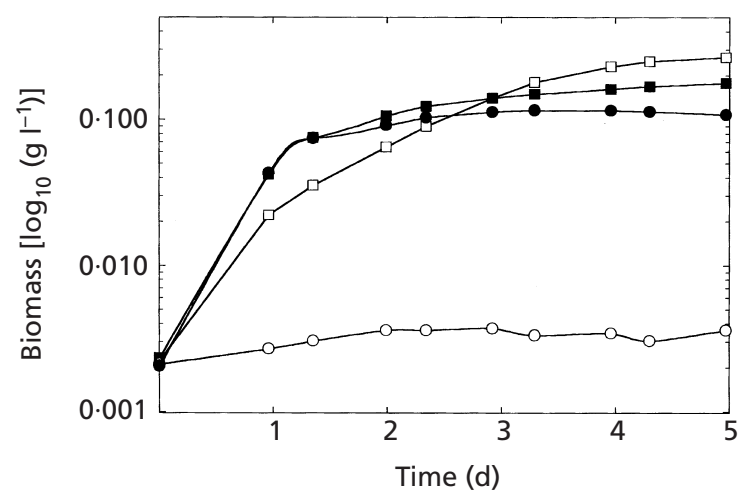

Fig. 2. Growth of $O$. oeni $M 42$ in $M B B$ plus $0.5 \mathrm{~g}_{\text {cysteine }} \mathrm{I}^{-1}$. $\bigcirc$, glucose + air-flow; $\square$, glucose $+\mathrm{N}_{2}$-flow; 0 , fructose + airflow; $\square$, fructose $+\mathrm{N}_{2}$-flow. Samples were incubated at $28^{\circ} \mathrm{C}$ and an initial $\mathrm{pH}$ of 4.8 . Cultures were stirred continuously at 200 r.p.m. 
Table 1. Quantification of substrates and end-products in the metabolism of hexoses by 0. oeni M42

O. oeni M42 was grown in MBBG or MBB plus fructose $(55 \mathrm{mM})$ under different aeration conditions. Samples were incubated at $28{ }^{\circ} \mathrm{C}$ and an initial $\mathrm{pH}$ of $4 \cdot 8$. All determinations were made in triplicate with at least two different extracts. ND, Not detected.

\begin{tabular}{|c|c|c|c|c|c|c|c|c|}
\hline \multirow{2}{*}{$\begin{array}{l}\text { Aeration } \\
\text { conditions }\end{array}$} & \multirow[t]{2}{*}{ Substrate } & \multirow{2}{*}{$\begin{array}{l}\text { Consumed sugar } \\
\qquad\left(\mathrm{mmol} \mathrm{l}^{-1}\right)\end{array}$} & \multicolumn{5}{|c|}{ Products $\left(\mathrm{mmol} \mathrm{l}^{-1}\right)$} & \multirow{2}{*}{$\begin{array}{c}\text { Carbon } \\
\text { recovery }(\%)\end{array}$} \\
\hline & & & Lactic acid & Acetic acid & Glycerol & Ethanol & Mannitol & \\
\hline \multirow[t]{2}{*}{ Anaerobic } & Glucose & $55 \cdot 0$ & $44 \cdot 4$ & $21 \cdot 7$ & $0 \cdot 2$ & $45 \cdot 8$ & ND & $95 \cdot 3$ \\
\hline & Fructose & $55 \cdot 0$ & $20 \cdot 2$ & $31 \cdot 1$ & $0 \cdot 0$ & $0 \cdot 4$ & $36 \cdot 9$ & $99 \cdot 1$ \\
\hline \multirow[t]{2}{*}{ Aerobic } & Glucose & $4 \cdot 5$ & $5 \cdot 3$ & $3 \cdot 6$ & $0 \cdot 3$ & $1 \cdot 1$ & $\mathrm{ND}$ & $97 \cdot 0$ \\
\hline & Fructose & $38 \cdot 4$ & $12 \cdot 7$ & $24 \cdot 4$ & $0 \cdot 3$ & $0 \cdot 9$ & $20 \cdot 4$ & $92 \cdot 0$ \\
\hline
\end{tabular}

* The carbon imbalance is attributed to some incorporation of hexoses into biomass and to the production of minor unidentified compounds.

Table 2. Activities of some enzymes involved in the regeneration of NAD(P)H by O. oeni M42

Measurements were made with crude extracts. All determinations were made in triplicate with at least two different extracts. ND, Not detected.

\begin{tabular}{|c|c|c|c|}
\hline Enzyme & Aeration condition & Cofactor & $\begin{array}{l}\text { Specific activity [mmol } \\
\left.\quad(\mathrm{g} \text { protein })^{-1} \mathrm{~min}^{-1}\right]\end{array}$ \\
\hline \multirow[t]{4}{*}{ NADH oxidase } & Aerobic & $\mathrm{NADH}$ & ND \\
\hline & Anaerobic & $\mathrm{NADH}$ & ND \\
\hline & Aerobic & $\mathrm{NADH}(+\mathrm{FAD})$ & $0.32 \times 10^{-3}$ \\
\hline & Anaerobic & $\mathrm{NADH}(+\mathrm{FAD})$ & ND \\
\hline \multirow[t]{4}{*}{ NADPH oxidase } & Aerobic & NADPH & $0 \cdot 61 \times 10^{-3}$ \\
\hline & Anaerobic & NADPH & ND \\
\hline & Aerobic & NADPH $(+$ FAD $)$ & $0 \cdot 82 \times 10^{-3}$ \\
\hline & Anaerobic & NADPH ( +FAD) & ND \\
\hline \multirow[t]{4}{*}{ Alcohol dehydrogenase } & Aerobic & NADH & ND \\
\hline & Anaerobic & NADH & 718 \\
\hline & Aerobic & NADPH & ND \\
\hline & Anaerobic & NADPH & 89 \\
\hline \multirow{4}{*}{$\begin{array}{l}\text { Acetaldehyde } \\
\text { dehydrogenase }\end{array}$} & Aerobic & NADH & ND \\
\hline & Anaerobic & NADH & $0 \cdot 34$ \\
\hline & Aerobic & NADPH & $\mathrm{ND}$ \\
\hline & Anaerobic & NADPH & $0 \cdot 02$ \\
\hline
\end{tabular}

growth was almost completely inhibited under aerated conditions. This inhibition of growth could be due either to the toxicity of $\mathrm{O}_{2}$ to cells, to the lack of $\mathrm{NAD}(\mathrm{P}) \mathrm{H}$ oxidases, or to the inactivation of the EFP enzymes. In anaerobic bacteria, if a peroxidase system for detoxification is not present, the $\mathrm{H}_{2} \mathrm{O}_{2}$ formed kills the cells. This effect was discarded in O. oeni M42 when it was found that cells cultured aerobically on fructose produced 20-fold more biomass than when cultured on glucose (Fig. 2), and $70 \%$ of the fructose was consumed.

NADH- and NADPH-oxidase activities were recorded under aerobic conditions for O. oeni (Table 2), although the reported levels were probably not sufficient to efficiently reoxidize the cofactors given that growth was negligible under aerobic conditions. On the other hand, cells grown under anaerobic conditions produced up to $0.30 \mathrm{~g}$ cell dry matter per litre of medium. The lack of significant activity for $\mathrm{NAD}(\mathrm{P}) \mathrm{H}$ oxidases under aerobic conditions has been previously reported in other LAB (Nuraida et al., 1992; Warriner \& Morris, 1995). Although NADH oxidases appear to be widely distributed among LAB, some strains lack them, whereas NADPH oxidases have only rarely been reported in LAB (Warriner \& Morris, 1995). Warriner \& Morris (1995) described the inability of Lactobacillus hilgardii to benefit from the presence of $\mathrm{O}_{2}$, which was explained by the lack of a $\mathrm{NAD}(\mathrm{P}) \mathrm{H}$ oxidase system. However, the 
Table 3. Concentration of cofactors and $N A D(P)^{+}: N A D(P) H$ ratios under different atmospheric conditions and growth phases

Glucose was used as the carbon source. Samples were incubated at $28{ }^{\circ} \mathrm{C}$ and an initial $\mathrm{pH}$ of $4 \cdot 8$.

The values shown are means of triplicate assays.

\begin{tabular}{|c|c|c|c|c|}
\hline \multirow[t]{2}{*}{ Aeration condition } & \multicolumn{3}{|c|}{ Cofactor $\left[\mathrm{mmol}(\mathrm{g} \text { protein })^{-1}\right]$} & \multirow{2}{*}{$\begin{array}{c}\text { Ratio } \\
{\left[\mathrm{NAD}(\mathbf{P})^{+}: \mathbf{N A D}(\mathbf{P}) \mathrm{H}\right]}\end{array}$} \\
\hline & $\mathrm{NAD}^{+}$ & $\mathrm{NADP}^{+}$ & $\mathrm{NAD}(\mathrm{P}) \mathrm{H}$ & \\
\hline Anaerobic & $12 \cdot 54$ & $12 \cdot 99$ & $1 \cdot 44$ & $17 \cdot 67$ \\
\hline Aerobic & $12 \cdot 88$ & $6 \cdot 61$ & $5 \cdot 01$ & 3.89 \\
\hline
\end{tabular}

absence of $\mathrm{NAD}(\mathrm{P})$ oxidases is not enough to explain low cell growth under aerobic conditions, because Lucey \& Condon (1986) reported that the aerobic growth of a mutant of Leuconostoc mesenteroides X2 lacking $\mathrm{NADH}$ oxidase was similar to its growth under anaerobic conditions, with the relative proportions of lactate and ethanol being the same under aerobic and anaerobic conditions. The low glucose consumption under aerobic conditions, and the low quantity of ethanol produced, suggested that the EFP was very inefficient. Ito et al. $(1974,1983)$ suggested that the effect of aeration on glycolysis in Leuconostoc mesenteroides was the consequence of the inability of cellular activities to reoxidize $\mathrm{NAD}(\mathrm{P}) \mathrm{H}$ via the EFP. The results of our enzyme assays to check EFP activity in O. oeni showed that both alcohol and acetaldehyde dehydrogenase $\left(\mathrm{NAD}^{+}\right.$and $\mathrm{NADP}^{+}$dependent) activities were high enough to support cell growth in glucose-containing anaerobic cultures (Table 2); however, these activities could not be detected in cell extracts transferred to aerobic conditions. This suggests that the EFP enzymes were inhibited by $\mathrm{O}_{2}$, thus stopping the normal way in which cofactors are reoxidized during the heterofermentative catabolism of glucose (Fig. 1, Table 2). Although it could be possible that $\mathrm{O}_{2}$ represses the synthesis of EFP enzymes instead of inhibiting the enzymes, it is reasonable to assume that the enzymes are constitutive, as has been reported for Leuconostoc mesenteroides (Sakamoto \& Komagata, 1996). This route is essential for reoxidation of the cofactors produced in the first steps of heterolactic sugar catabolism, and inhibiting this pathway would seriously compromise cellular development. There is evidence that $\mathrm{O}_{2}$ inhibits enzyme activity of $\mathrm{O}$. oeni in vivo: transfer of an aliquot of a bioreactor culture grown on glucose from anaerobic to aerobic conditions resulted in loss of activity of EFP enzymes after $1 \mathrm{~h}$. In addition, we found that normal activity in anaerobic extracts dramatically decreased when they were flushed with air.

Oxidized and reduced cofactors were quantified in extracts of cells from cultures grown on glucose aerobically and anaerobically. No differences were found in the $\mathrm{NAD}^{+}$concentration, but the $\mathrm{NADP}^{+}$concentration was half as low in the aerobic extracts as compared to the anaerobic extracts (Table 3 ). The ratio between oxidized and reduced cofactors was $4 \cdot 5$-fold higher in extracts cultured under anaerobic conditions than those cultured under aerobic conditions (Table 3). These results suggest that $O$. oeni cells grown aerobically on glucose did not reoxidize the $\mathrm{NAD}(\mathrm{P}) \mathrm{H}$ properly because the EFP enzymes were inhibited by $\mathrm{O}_{2}$, and as a consequence growth was seriously compromised.

Results obtained from the analysis of the end-products of fructose catabolism showed that this sugar was mainly oxidized to acetate $\left[Y_{\text {acetate }}=0.63 \mathrm{~mol}\right.$ acetate $\left.(\text { mol sugar })^{-1}\right]$, mannitol $\left[Y_{\text {mannitol }}=0.53 \mathrm{~mol}\right.$ mannitol $\left.(\mathrm{mol} \text { sugar })^{-1}\right]$ and lactate $\left[Y_{\text {lactate }}=0.33 \mathrm{~mol}\right.$ lactate $(\text { mol sugar })^{-1}$, whereas ethanol was hardly produced (Table 1). In this case, cells attained a final biomass of $0 \cdot 12 \mathrm{~g} \mathrm{l}^{-1}, 2 \cdot 4$-fold higher than on glucose, and although EFP enzymes were inhibited by $\mathrm{O}_{2}$, the reoxidation of $\mathrm{NAD}(\mathrm{P}) \mathrm{H}$ was achieved due to the reduction of fructose to mannitol, via mannitol dehydrogenase (Veiga-daCunha et al., 1992, 1993). This was confirmed by the relative quantities of mannitol and ethanol derived from fructose (Table 1). It was also observed that twofold more acetate was produced with respect to lactate, implying that some pyruvate was channelled to acetyl phosphate by pyruvate oxidase, resulting in extra ATP production, which improves growth (Diviès et al., 1994). Cells grown on fructose, either anaerobically or aerobically, exhibited lower $X_{\max }$ values than cells grown on glucose under anaerobic conditions (Fig. 2). This was a consequence of the fact that a large proportion of the fructose was converted to mannitol without gaining ATP, whereas glucose was fully transformed to lactate, ethanol, acetate and $\mathrm{CO}_{2}$, with a gain of at least $1 \mathrm{~mol}$ ATP per mol glucose.

\section{Aerobic growth in a glucose medium supplied with reducing substrates}

The previous results suggest that adding reducing agents to MBBG under aerobic conditions could improve the regeneration of cofactors to some extent. Given that $\mathrm{ADH}$ and acetaldehyde dehydrogenase were inhibited by $\mathrm{O}_{2}$ in $\mathrm{O}$. oeni M42, pyruvic acid, fructose or cysteine were added to MBBG in order to test the ability of these products to reoxidize $\mathrm{NAD}(\mathrm{P}) \mathrm{H}$ and, hence, to improve 


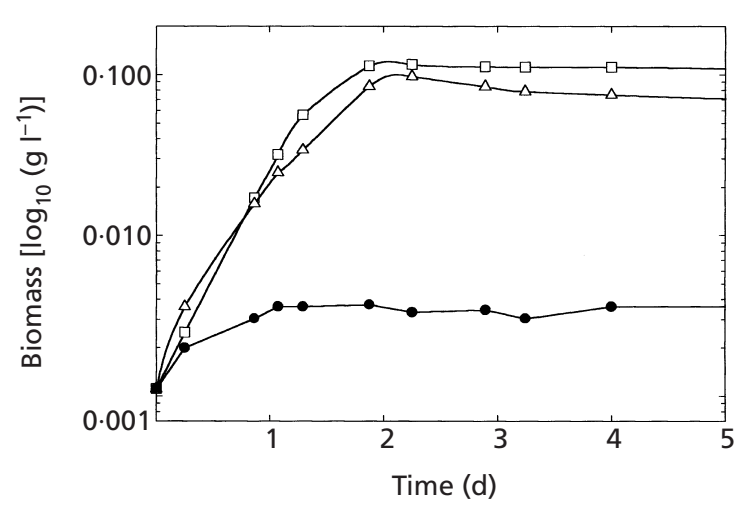

Fig. 3. Aerobic growth of $O$. oeni $M 42$ in MBB containing: glucose, 0 ; glucose + pyruvic acid, $\triangle$; glucose + fructose, $\square$. Samples were incubated at $28{ }^{\circ} \mathrm{C}$ and an initial pH of 4.8 . Cultures were stirred continuously at 200 r.p.m.

growth. Growth on glucose alone was negligible (Fig. 3). When pyruvic acid was supplied it was completely metabolized to lactic acid and acetic acid, reoxidizing $\mathrm{NADH}$ and leading to higher biomass production (Fig. 3). The stoichiometrical balance showed a twothreefold greater yield of acetic acid than when O. oeni was grown on glucose alone (Table 4), whilst higher levels of ATP $\left[Y_{\mathrm{ATP}}=0.11 \mathrm{~mol}\right.$ ATP $\left.(\mathrm{mol} \text { sugar })^{-1}\right]$ were produced. The addition of pyruvic acid resulted in 20 -fold higher levels of biomass production $\left(X_{\max }=\right.$ $0.09 \mathrm{~g} \mathrm{l}^{-1}$ ) than those seen in its absence (Fig. 3). Nevertheless, as lactate dehydrogenase can reoxidize $\mathrm{NADH}$, but not NADPH, addition of pyruvic acid to MBBG does not allow complete reoxidation of NADPH generated in the first reactions of the carbohydrate pathway and, therefore, glucose could not have been exhausted. Ito et al. (1983) reported a beneficial effect of pyruvic acid on Leuconostoc mesenteroides growth when it was used as an external electron acceptor.

The addition of the same quantity of fructose $(20 \mathrm{mM})$ to MBBG allowed its reduction to mannitol, with $\mathrm{NAD}(\mathrm{P}) \mathrm{H}$ molecules being oxidized via mannitol dehydrogenase (Fig. 1). Hence, $80 \%(\mathrm{w} / \mathrm{w})$ fructose was reduced to mannitol to generate reducing equivalents, while the remainder, together with $7 \cdot 1 \mathrm{mM}$ glucose, was equimolarly converted to lactate and acetate (Table 4). This permitted $X_{\max }=0 \cdot 10 \mathrm{~g} \mathrm{l}^{-1}$, a little higher than that obtained with pyruvic acid (Fig. 3). The simultaneous consumption of both glucose and fructose led to higher yields of acetate, compared to those seen in glucose cultures. Glucose is known to be metabolized in the heterolactic pathway, whereas fructose is mainly devoted to $\mathrm{NAD}(\mathrm{P}) \mathrm{H}$ reoxidation in the mannitol pathway (Maicas et al., 1999).

The data presented in Table 5 indicate that the addition of quantities of cysteine, ranging from 0-30 mM, have a beneficial effect on glucose consumption and bacterial growth. The higher the quantity of supplied cysteine, the higher the degradation of glucose and the greater final biomass reached. When $30 \mathrm{mM}$ cysteine was added, biomass production $\left(X_{\max }=0.28 \mathrm{~g} \mathrm{l}^{-1}\right)$ and the consumption of glucose mirrored that in an $\mathrm{O}_{2}$-free atmosphere. Lactic acid and ethanol production from cultures grown on MBBG plus cysteine were shown to be equimolar, by analysis of the end-products of metabolism. The other end-product found in the culture broth was acetic acid, the yield of which varied from $0 \cdot 2-0 \cdot 6$ (where yield is mmol acetic acid produced $1^{-1}$ versus mmol glucose consumed $1^{-1}$ ), depending on the levels of cysteine supplied (Table 5). Part of this acetate would come from cysteine that was metabolized via pyruvate to yield extra ATP, as has been described in other LAB (Bruinenberg et al., 1997). Additionally, two extra NADH molecules were reoxidized.

The ethanol: lactic acid ratio was $1 \cdot 0: 1 \cdot 1$ when cysteine was added, showing that the EFP works and leads to the heterolactic catabolism of glucose under aerobic conditions. The combination of the thiol groups of cysteine with $\mathrm{O}_{2}$ would avoid the direct $\mathrm{O}_{2}$ inhibition of EFP enzymes. ADH and acetaldehyde dehydrogenase activities were not detected in extracts (Table 2); however, when these extracts were added with $3 \mathrm{mM}$ cysteine some activity was recovered. The effect of cysteine on the enzyme activity was more accurately assayed in anaerobic extracts, as the protein concentration in aerobic extracts was very low. Aliquots of the anaerobic extract, with or without $3 \mathrm{mM}$ cysteine, were air-

Table 4. Quantification of substrates and end-products in the aerobic metabolism of hexoses by 0 . oeni M42

O. oeni M42 was grown in MBBG plus reducing substrates, where indicated. Samples were incubated at $28^{\circ} \mathrm{C}$ and an initial $\mathrm{pH}$ of 4.8. All determinations were made in triplicate with at least two different extracts. ND, Not detected.

\begin{tabular}{|c|c|c|c|c|c|c|c|c|}
\hline \multicolumn{3}{|c|}{ Consumed substrates $\left(\mathrm{mmol} \mathrm{l}^{-1}\right)$} & \multicolumn{5}{|c|}{ Products $\left(\mathrm{mmol} \mathrm{l}^{-1}\right)$} & \multirow{2}{*}{$\begin{array}{c}\text { Carbon } \\
\text { recovery }(\%)\end{array}$} \\
\hline Glucose & Fructose & Pyruvic acid & Lactic acid & Acetic acid & Glycerol & Ethanol & Mannitol & \\
\hline $4 \cdot 5$ & 0 & 0 & $5 \cdot 3$ & $3 \cdot 6$ & $0 \cdot 3$ & $1 \cdot 1$ & ND & $97 \cdot 0$ \\
\hline $7 \cdot 1$ & $20 \cdot 0$ & 0 & $9 \cdot 5$ & $9 \cdot 0$ & $0 \cdot 7$ & $0 \cdot 4$ & $16 \cdot 0$ & $89 \cdot 4$ \\
\hline $3 \cdot 6$ & 0 & $20 \cdot 0$ & $19 \cdot 1$ & $10 \cdot 4$ & $0 \cdot 2$ & $1 \cdot 1$ & $\mathrm{ND}$ & $99 \cdot 1$ \\
\hline
\end{tabular}

* The carbon imbalance is attributed to some incorporation of hexoses into biomass and to the production of minor unidentified compounds. 
Table 5. Quantification of substrates and end-products in the metabolism of glucose by O. oeni M42

O. oeni M42 was cultured aerobically in MBBG plus different quantities of cysteine. Samples were incubated at $28^{\circ} \mathrm{C}$ and an initial $\mathrm{pH}$ of $4 \cdot 8$. All determinations were made in triplicate with at least two different extracts.

\begin{tabular}{|c|c|c|c|c|}
\hline \multicolumn{2}{|c|}{ Substrates $\left(\mathrm{mmol} \mathrm{l}^{-1}\right)$} & \multicolumn{3}{|c|}{ Products $\left(\mathrm{mmol} \mathrm{l}^{-1}\right)$} \\
\hline Cysteine added & Glucose consumed & Lactic acid & Acetic acid & Ethanol \\
\hline $0 \cdot 0$ & $1 \cdot 0$ & $1 \cdot 0$ & $0 \cdot 0$ & $1 \cdot 0$ \\
\hline $1 \cdot 5$ & $21 \cdot 5$ & $19 \cdot 8$ & $4 \cdot 6$ & $20 \cdot 0$ \\
\hline $7 \cdot 5$ & $26 \cdot 4$ & $23 \cdot 4$ & $16 \cdot 7$ & $26 \cdot 4$ \\
\hline $15 \cdot 0$ & $33 \cdot 7$ & $29 \cdot 9$ & $18 \cdot 5$ & $33 \cdot 7$ \\
\hline $30 \cdot 0$ & $52 \cdot 5$ & $46 \cdot 5$ & $21 \cdot 7$ & $52 \cdot 5$ \\
\hline
\end{tabular}

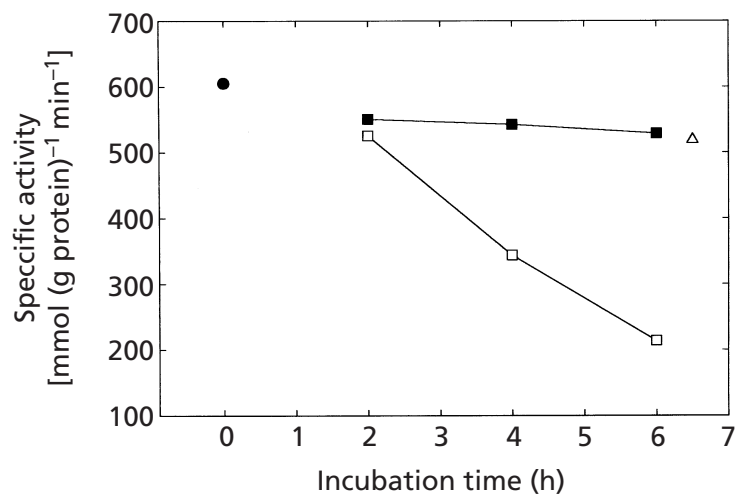

Fig. 4. Activity of ADH. Unflushed anaerobic extract; $\square$, airflushed extract without cysteine; $\boldsymbol{\square}$, air-flushed extract with $3 \mathrm{mM}$ cysteine; $\triangle$, air-flushed extract incubated without cysteine for $6 \mathrm{~h}$, followed by incubation with $3 \mathrm{mM}$ cysteine for $30 \mathrm{~min}$. All determinations were made in triplicate.

flushed. The specific activity of $\mathrm{ADH}$, the most active enzyme in this pathway, before contact with air was $605 \mathrm{mmol}$ (g protein $)^{-1} \mathrm{~min}^{-1}$. After air-flushing (2, 4 and $6 \mathrm{~h}$ ) the ADH activity decreased progressively (Fig. 4). An aliquot of the $6 \mathrm{~h}$ aerated extract was subsequently incubated with $3 \mathrm{mM}$ cysteine for $30 \mathrm{~min}$ prior to enzyme determination, and $90 \%$ of the initial activity was recovered. The addition of $3 \mathrm{mM}$ cysteine to the extracts during aeration also permitted a high maintenance of activity, supporting $\mathrm{O}_{2}$-quenching by cysteine (Fig. 4).

Cysteine is usually included in the composition of media used to cultivate LAB because it is an antioxidant. In this work we have demonstrated that the provision of cysteine to MBBG under aerobic conditions enhances the catabolism of glucose and, as a consequence, the growth of O. oeni.

In conclusion, we have proved that $\mathrm{O}$. oeni M42 does not benefit from the presence of $\mathrm{O}_{2}$ in the atmosphere, as has already been observed for other LAB (Lucey \& Condon, 1986). The absence of active $\mathrm{NAD}(\mathrm{P}) \mathrm{H}$ oxi- dases and the inhibition of EFP enzymes by $\mathrm{O}_{2}$ resulted in a low $\mathrm{NAD}(\mathrm{P})^{+}: \mathrm{NADP}(\mathrm{H})$ ratio and, as a consequence, growth of O. oeni M42 on MBBG was negligible (Fig. 3). Growth can be improved by adding other substrates that act as electron acceptors, such as fructose (Nuraida et al., 1992) or cysteine, to glucose cultures. This is of great interest when the objective is to obtain the highest biomass possible, as in the manufacture of commercial starters for malolactic fermentation.

\section{ACKNOWLEDGEMENTS}

This work was partially supported by grants from the Comisión Interministerial de Ciencia y Tecnología (ALI930246) and by a grant from the MEC (Spanish Government) to S. M. The collaboration of À. Natividad and P. GonzálezCabo in some experiments is gratefully acknowledged. English text corrected by Fabiola Barraclough.

\section{REFERENCES}

Anders, R. F., Hogg, D. M. \& Jago, G. R. (1970). Formation of hydrogen peroxide by group $\mathrm{N}$ streptococci and its effect on their growth and metabolism. Appl Environ Microbiol 19, 608-612.

Bruinenberg, P. G., de Roo, G. \& Limsowtin, K. Y. (1997). Purification and characterization of cystathione $\gamma$-lyase from Lactococcus lactis subsp. cremoris SK11: possible role in flavor compound formation during cheese maturation. Appl Environ Microbiol 63, 561-566.

Caspritz, G. \& Radler, F. (1983). Malolactic enzyme of Lactobacillus plantarum. J Biol Chem 258, 4907-4910.

Cogan, T. M. \& Jordan, K. N. (1994). Metabolism of Leuconostoc bacteria. J Dairy Sci 77, 2704-2717.

Cogan, J. F., Walsh, D. \& Condon, S. (1989). Impact of aeration on the metabolic end-products formed from glucose and galactose by Streptococcus lactis. J Appl Bacteriol 66, 77-84.

Diviès, C., Frey, L., Hubert, J. C. \& de Roissart, H. (1994). Métabolisme d'autres substrats carbonés par les bactéries lactiques. In Bactéries Lactiques, vol. I, pp. 291-307. Edited by H. de Roissart \& F. M. Luquet. Uriage, France: Lorica.

Firme, M. P., Leitão, M. C. \& San Romão, M. V. (1994). The metabolism of sugar and malic acid by Leuconostoc oenos: effect of malic acid, $\mathrm{pH}$ and aeration conditions. J Appl Bacteriol 76, 173-181. 
Ito, S., Hashiba, H. \& Eguchi, Y. (1974). Adaptative control of the ethanol-forming system in heterolactic acid bacteria. J Biochem 75, 577-581.

Ito, S., Kobayashi, T., Ohta, Y. I. \& Akiyama, Y. (1983). Inhibition of glucose catabolism by aeration in Leuconostoc mesenteroides. J Ferment Technol 61, 353-358.

Kelly, A. F. \& Patchett, R. A. (1996). Lactate and acetate production in Listeria innocua. Lett Appl Microbiol 23, 125-128.

Klingenberg, H. U. (1985). Methods of Enzymatic Analysis. 3rd edn, vol. VII. New York: Academic Press.

Lucey, C. A. \& Condon, S. (1986). Active role of oxygen and NADH oxidase in growth and energy metabolism of Leuconostoc. J Gen Microbiol 132, 1789-1796.

Maicas, S., González-Cabo, P., Ferrer, S. \& Pardo, I. (1999). Production of Oenococcus oeni biomass to induce malolactic fermentation in wine by control of $\mathrm{pH}$ and substrate addition. Biotechnol Lett 21, 349-353.

Murphy, M. G. \& Condon, S. (1984). Correlation of oxygen utilization and hydrogen peroxide accumulation with oxygen induced enzymes in Lactobacillus plantarum cultures. Arch Microbiol 138, 44-48.

Nuraida, L., Grigolava, I., Owens, J. D. \& Campbell-Platt, G. (1992). Oxygen and pyruvate as external electron acceptors for Leuconostoc spp. J Appl Bacteriol 72, 517-522.

Pardo, I. \& Zúñiga, M. (1992). Lactic acid bacteria in spanish red rosé and white musts and wines under cellar conditions. J Food Sci 57, 392-405.
Plihon, F., Taillandier, P. \& Strahaiano, P. (1995). Oxygen effect on batch cultures of Leuconostoc mesenteroides: relationship between oxygen uptake, growth and end-products. Appl Microbiol Biotechnol 43, 117-122.

Sakamoto, M. \& Komagata, K. (1996). Aerobic growth of and activities of NADH oxidase and NADH peroxidase in lactic acid bacteria. J Ferment Bioeng 82, 210-216.

Salou, P., Loubière, P. \& Pareilleux, A. (1994). Growth and energetics of Leuconostoc oenos during cometabolism of glucose with citrate or fructose. Appl Environ Microbiol 60, 1459-1466.

Veiga-da-Cunha, M., Firme, P., San Romão, V. \& Santos, H. (1992). Application of ${ }^{13} \mathrm{C}$ nuclear magnetic resonance to elucidate the unexpected biosynthesis of erythritol by Leuconostoc oenos. Appl Environ Microbiol 58, 2271-2279.

Veiga-da-Cunha, M., Santos, H. \& van Schaftingen, E. (1993). Pathway and regulation of erythritol formation in Leuconostoc oenos. J Bacteriol 157, 3941-3948.

Warriner, K. S. R. \& Morris, J. G. (1995). The effects of aeration on the bioreductive abilities of some heterofermentative lactic acid bacteria. Lett Appl Microbiol 20, 323-327.

Wibowo, D., Eschenbruch, R., Davis, C. R. \& Lee, T. H. (1985). Occurrence and growth of lactic acid bacteria in wine: a review. Am J Enol Vitic 36, 302-313.

Received 13 March 2001; revised 12 September 2001; accepted 17 September 2001. 